\title{
Supplying ships with safe drinking-water
}

\author{
Rosanda Mulićc ${ }^{1,}$, Iris Jerončić Tomić ${ }^{1}$ \\ ${ }^{1}$ School of Medicine, University of Split, Croatia \\ ${ }^{2}$ Faculty of Maritime Studies, University of Split, Croatia
}

\begin{abstract}
Background: Ships are supplied with water from various sources: directly from the public utility system at the port, from water supply vessels or barges, bottled water, ice or, if water production on board is possible, through processes such as desalination and reverse osmosis. All elements of a ship's water supply chain are exposed to the influence of different factors that may have a negative impact on water safety on board or on human health. Potable water standards are the same for vessels and for land-based facilities. In recognition of the importance of drinking water and the impact it can have on human health, stringent quality standards have been laid down in national and global regulations. The aim of the study was to describe the water supply system on ships and its weak points, as well as the health risks that the use of polluted drinking water can entail.

Materials and methods: The Medline Database has been searched using the following key words: ship, water supply, waterborne infections. Other available literature has also been used, as well as national and international regulations on drinking-water safety.

Results and Conclusions: Drinking water on ships is managed in line with the hygienic and health standards applied along the entire supply chain, from the source to the point of consumption. Regardless of the sanitary control system used by the authorised institutions on the ground, ship officers must oversee the entire water supply and distribution system on board, as well the water production systems if these exist. That means that they must be well aware of all of the fundamental facts of the supervision system, as well as the weaknesses of the water supply system. Maritime studies students, future deck officers and engine officers, must all receive training on the weak points of the system and on water contamination prevention.
\end{abstract}

(Int Marit Health 2020; 71, 2: 123-128)

Key words: potable water, ship water supply, waterborne infections, safe drinking-water

\section{INTRODUCTION}

All human beings need water; it is a prerequisite for their survival and for the normal functioning of their organisms. The Drinking Water Directive of the European Union points to the fact that the ecosystem, the society and the economy all need sufficient quantities of fresh water to grow and develop. Drinking water is the only staple that is used by all people on Earth, regardless of their religion, race, socioeconomic status or location [1-3].

On ships, the functioning of the water supply system is the responsibility of the engine officer, while the second mate or the captain are responsible for monitoring the quantity of water in the tanks and water safety. On the ground, health-care departments are tasked with an- alysing water samples and assessing water safety. The World Health Organization (WHO) warns of water-related problems, especially in developing countries. A variety of infections intestinal diseases are transmitted through the use of unsafe drinking water [2]. To suppress outbreaks of such diseases, improved sanitary conditions, safe drinking water and proper sanitary infrastructure must be put in place. On the other hand, poor water management can lead to the transmission of infectious diseases or to chemical poisoning. Research has shown that more than 100 outbreaks are ship-related, one fifth of which was attributed to water [4-7]. The number of infections on board passenger ships is rising and poses a significant public health problem considering the number of people who could be infected 
as well as the financial costs this would entail for the companies [5]. Most waterborne epidemics on board ships involve drinking water contaminated with pathogens from human or animal excretions. Diseases related to chemical water pollution are also on the rise [4-6, 8]. Outbreaks transmitted via contaminated water are most often linked to poor quality of water at the time of loading onto the ship. In order to prevent water-related diseases, vessels must be supplied with water that is safe for consumption in line with the 2017 WHO Guidelines for Drinking-Water Quality or relevant national standards, depending on whose criteria is more stringent. Even if water in the port is safe, due to the risk points at which it can become contaminated, there is no guarantee that it will remain safe during transfer and storage on board. In case of drinking-water production from seawater, on ships, the process must be monitored and the resulting water disinfected if necessary [2-9].

The objective of this paper was to describe the drinking-water supply system for vessels and its weak points, as well as the health risks posed by using contaminated drinking-water.

\section{MATERIALS AND METHODS}

In this paper, we used data from available literature. The Medline Database was searched for key words: ship, water supply, waterborne infections. Other available literature was also used, as well as national and international regulations on drinking-water safety.

\section{DRINKING-WATER SUPPLY SYSTEM ON SHIPS}

The drinking-water supply and transport system for ships consists of: the source of drinking water coming to the port, the transfer and delivery system and the ship's water system. The transfer and delivery system involves hydrants, water pipes, hoses, water supply and reception vessels, and provides ample opportunities for drinking-water contamination. A ship's water system includes water storage, distribution and production on board [9]. In each of these elements of the supply and distribution chain, water can be contaminated and will thus become unsafe.

Ports get drinking water for ships from public or private supply systems and are usually equipped with special systems to manage the water once it enters the port. After going through the port water system, water is transferred to ships via water tanker vessels and barges. The water that comes to the ship from the port water system, including the water from water tankers and barges, can only come from water sources and storage facilities that have safe drinking water of a quality that is in line with WHO standards or national regulations. The water supplied in ports must be adequate for distribution and consumption without any further processing, unless water quality needs to be maintained in the distribution system (e.g. additional disinfection or addition of anti-corrosion chemicals) [6-9]. In addition to the physical and chemical characteristics, special attention should be paid to the microbiological quality of water. European Union Member States have been aligning their water safety parameters with the European Union Drinking Water Directive, ensuring that water for human consumption is wholesome and clean $[6,7]$. The equipment used for water transfer and distribution, be it new or repaired, must be disinfected prior to being put into use. In case water used for supplying ships with drinking-water is contaminated at the port, the port must take the necessary corrective measures and inform the person responsible for water storage, in order to prevent contaminated water from being transported onto the ship. Preventive measures aimed at preserving water safety and quality include making sure that the pressure in the pipelines is positive at all times so that the flow of water is not reversed. In addition to that, there must be no link between the drinking water system and other pipelines. All components, meters and other gear must be handled in a sanitarily acceptable manner [6-11].

Water tanker ships are specially designed and equipped to receive and supply water whenever direct delivery from the shore is not possible. These ships have water tanks, water pipes and an independent supply pipeline taking drinking water into the ship's systems. In order to avoid the contamination of water in the ship's water system, the reception, handling, storage and delivery of water must all be done in controlled, sanitary conditions. All pipes, fittings and tools must be kept in closed and clean compartments. Operators must be well trained on proper, hygienic and sanitary handling of water. All pipes and connections must be cleaned and disinfected on a regular basis. Water tankers must have the approval of the competent port health-care body or other competent health-care authority, confirming that they dispose of the necessary equipment for supplying vessels with water in line with the sanitary rules and regulations $[7,9,11,12]$.

In addition to being transported to vessels in liquefied form, water can also be shipped in bottles or as ice. The ice used to supply ships from ashore or that has been produced on board and is used for drinks and cooling is classified as food, and regulations on the safety of ice used on ships are applicable for both packaged water and ice for human consumption. According to WHO Guidelines, ice coming into contact with food or drinks must be produced from safe potable water. Sources ashore must be checked by local health care institutions, and ice delivery from shore to ship must be done in a sanitarily acceptable manner. The person in charge of transporting ice must wear clean clothes, gloves and boots. Ice should be kept in a clean storage facility, lifted from the surface by means of deck 
boards or other devices allowing drainage and free flow of air. All ice produced on ships must be treated and stored in a sanitarily acceptable manner. Water on board ships is stored in tanks. Many ships use the desalination process to produce their own drinking water $[11,12]$.

\section{DRINKING-WATER SYSTEM ON SHIPS}

Whenever possible, it is useful to set up only one system to supply potable water for drinking, cooking, dishwashing, laundering and personal hygiene purposes, although sometimes two or three water systems are put in place, e.g. the potable (drinking), the sanitary and the wash water system. A wash water system can be used to supply water to the sink, the laundry room, for cleaning, for heated dishwashing water and other special purposes. All taps that do not have potable water need to be properly labelled, e.g. "unfit for drinking" [13]. Pipelines on board ships consist of a number of tubes used for the distribution of freshwater, seawater, sewage and fuel, located in a confined space. These are usually rather comprehensive and complex, making their inspection, repair and maintenance difficult. When laying new pipes or repairing existing ones, precautionary hygienic measures must be taken, for which the crew must be adequately trained. When designing pipelines, it is very important to minimise the points where water could collect and become warm $\left(>25^{\circ} \mathrm{C}\right)$. For example, temperature-control valves that prevent overheating should be installed as close to the point of use as possible in order to reduce the formation of warm water pockets. The number of distribution system dead ends should also be minimised [7]. If hot-water and cold-water piping are laid side by side, they must be thermally insulated to prevent the pipes from heating up or cooling and to prevent bacterial growth. All piping components must be resistant to water temperatures over $90^{\circ} \mathrm{C}$ for thermal disinfection purposes [7].

\section{DRINKING-WATER TANKS}

Drinking-water tanks must not have drainage lines or any pipes carrying wash water, salt water or other liquids going through them. If that is not possible, then pipes going through potable water tanks must be placed in a watertight tunnel that is self-draining. Waste waters sewages, wash-water tank manholes or anything of the like that could contaminate potable water should not go over the potable water tanks. It is also best if toilets and bathroom spaces do not extend over any part of a deck that forms the top of a potable water tank $[13,14]$. All appliances for measuring potable water tank levels should be performed so as to prevent the entry of contaminated matters or liquids into the potable water tank. A graduated steel tape with a weight (probing tape) is used for measuring water tank levels. The measurements are performed in the probing tube (probe) which extends from the bottom of the tank to the deck. WHO recommends performing regular inspections of empty tanks, e.g. once a year. In cases when people enter tanks, they should wear clean protective clothing, a disposable face mask, disposable rubber gloves and light-coloured rubber boots, very clean, and used only in potable water tanks. Boots and all tools used in the tank must be disinfected prior to entering the tank. Persons with acute illnesses (e.g. diarrhoea) are banned from entering the potable water tank [7].

\section{DRINKING-WATER PRODUCTION ON SHIPS}

Ships can produce their own water using various processes, such as reverse osmosis or sea water evaporation. On large passenger ships, freshwater generators can produce up to 500 tonnes of water per day, while cargo ships can produce around 30 tonnes per day. The daily demand for water on passenger ships is around 200 litres of water per passenger and around 60 litres per crew member on cargo ships [12]. According to International Organization for Standardisation (ISO) standards, water that has been produced from sea water at temperatures below $80^{\circ} \mathrm{C}$ must be disinfected before it can be defined as potable [6]. Sea water sources can contain hazards that are not present in freshwater systems and these include various algae and cyanobacteria, certain free-living bacteria (including Vibrio species such as V. parahaemolyticus and V. cholerae) and some chemicals, such as boron and bromide, which are abundant in seawater. Due to contamination risks, sea water cannot be used for desalination if taken from up to 12 nautical miles from the shore [12]. In Croatia, the quality and safety of water samples is tested by county health-care institutes and in other countries by the competent health-care institutions.

\section{LEGAL PROVISIONS CONCERNING DRINKING-WATER SAFETY}

The first directive on the quality of drinking water was adopted at the level of the European Union in 1975 (Council Directive 75/440/EEC of 16 June 1975, followed by the first common drinking water directive adopted in 1980 and amended in 1998). It aimed at protecting public health from the hazardous effects of all forms of pollution. In 2018 amendments to the Directive on the quality of water intended for human consumption were proposed with the aim of improving consumer information as well as the quality of and access to drinking water. The standards for drinking-water quality are the same for land-based and floating structures. The Directive on the quality of water intended for human consumption established European Union's drinking-water quality standards that are binding for all Member States and entail monitoring and control obligations. Parameters have been divided into three groups: 
- microbiological parameters: related to the presence of Escherichia coli and enterococci;

- chemical parameters: the share of particular substances such as metals and organic compounds as well as generic substances such as pesticides and by-products of disinfection;

- indicator parameters enabling insight into the purification process and the organoleptic and aesthetic quality of drinking water which includes microbiological, chemical and radiological parameters.

Water intended for human consumption is all water, either in its original state or after treatment, intended for drinking, cooking, food preparation or other domestic purposes, regardless of its origin and whether it is supplied from a public distribution network, from a tanker, or in bottles or containers. It is also all water used in undertakings for the manufacture, processing, preservation or marketing of products or substances intended for human consumption $[2,6$, $7,9,15]$. Pursuant to the Directive and the Act on Water for Human Consumption, water intended for human consumption shall be considered safe, or wholesome and clean, if it:

- is free from any micro-organisms and parasites and from any substances which, in numbers or concentrations, constitute a potential danger to human health;

- is free from harmful substances in such concentrations that they alone or in combination with other substances pose a threat to human health;

- does not exceed the values of water wholesomeness and cleanliness parameters prescribed in the ordinances in line with the legal provisions $[1,15]$.

The main problem on ships is the microbial risk and the risk related to toxic chemicals. In the Guidelines on Drinking-Water Quality, a wide spectrum of contaminants has been identified, including microorganisms, inorganic and synthetic organic chemicals, disinfection by-products and radionuclides, which can reach dangerous concentrations in drinking water supply chains. Safe drinking-water, as defined by the Guidelines, does not pose a significant health risk during a life-time of consumption, including various sensitivities that may occur between life stages $[9,10]$. Convention $\mathrm{C} 133$ of the International Labour Organisation (ILO) - Accommodation of Crews defines the minimum standards for drinking water supply. All ships must provide sufficient quantities of water for drinking, food preparation, cooking, dishwashing, etc. (drinking-water) and water for sanitary purposes, e.g. washing up, bathing and showering (fresh water), taking into consideration the area of navigation, duration of the voyage and number of persons on board. The quality of water must meet all recognised sanitary norms for drinking-water and fresh water [14]. The Maritime Labour Convention (2006) contains minimum international standards on working conditions for seafarers on ships
[16], which embodies more than 65 up-to-date standards of existing international maritime labour adopted over the past 80 years. Regulation 3.2 of the Maritime Labour Convention ensures that seafarers have access to good quality drinking water. Every Member to the Convention shall ensure that ships that fly its flag carry on board and serve drinking water of appropriate quality provided under regulated hygienic conditions $[16,17]$. The Life-Saving Appliance Code (LSA) (International Maritime Organisation [IMO], 2010) contains additional information on the need for drinking-water in rescue boats [18]. In addition to the abovementioned, there are seven international standards that are issued by the ISO concerning the design and construction of ship water supply systems and the assessment of drinking-water quality. International Health Regulations (IHR, 2005) contain provisions obliging WHO States Parties to develop basic port infrastructure, including drinking-water supply [19]. In line with Articles 22(b), 22(e) and 24(c) of the IHR, States Parties shall take all measures to ensure that international transporters (conveyance operators) keep their conveyances away from the sources of contamination and infection, while the competent authorities shall be responsible for keeping facilities in international ports in a sanitarily acceptable condition and for the supervision of the removal and safe disposal of any contaminated water or food from a conveyance. All conveyance operators are responsible for setting up measures to control and eliminate the sources of infection or contamination, including the water supply system $[9,12,13,20,21]$.

\section{POSSIBLE CONSEQUENCES OF UNSAFE WATER ON HUMAN HEALTH}

Unsafe water on ships is a potential source of viral, bacterial and parasite infections, as well as chemicals poisoning, and is mostly associated with swallowing water contaminated by human or animal dejecta. The evidence from the literature suggests that water availability has an important influence on health and diarrhoea incidence in particular [22, 23]. On cruise ships, gastroenteritis affects one to six passengers in 1,000 cruise trips [24]. In recent years, passenger ships have increased in number and size, which is a risk factor for diseases transmitted via food, water or contact. Research into Enterotoxigenic E.coli (ETEC)-caused gastroenteritis outbreaks has shown a link to the consumption of ice-cooled drinks on board ships and of tap water. However, a connection has also been established between contaminated water and food and the transmission of ETEC infections ashore. On cruise ships, Norovirus infections pose a major problem [4, 6-10, 19-21, 24-27]. Roney and associates described waterborne epidemics on ships between 1970 and 2003 based on data published in articles quoted in MEDLINE, Em base and Cab Health [4]. According to that research, more than 6,400 people were affected in 
the 21 reported outbreaks of waterborne diseases associated with ships between January 1, 1970 and June 30, 2003. Causes of outbreaks are linked to contaminated port water, inadequate treatment, improper loading techniques, cross connections between potable and non-potable water, poorly designed and installed drinking-water tanks and inadequate disinfection [4]. Enterotoxigenic E. coli was a proven pathogen in seven outbreaks (33.3\%), noroviruses in three (14.3\%), and Salmonella typhi, Salmonella enteritidis, Shigella flexneri, Cryptosporidium spp in one outbreak each (4.8\%). One outbreak was due to a chemical (hydroquinone), and in five outbreaks no pathogen was determined [4, 6, 13, 20, 28]. In addition to gastrointestinal infections, respiratory tract infections can also be transmitted via water (aerosol). Poorly kept air-conditioning systems or unwanted/inadequate water heating can contribute to the reproduction of numerous pathogens including Legionella spp. Breathing-in contaminated aerosols can lead to an outbreak in legionellosis, a severe and sometimes life-threatening illness. Most susceptible are elderly persons with multimorbidity and immunocompromised persons [7, 27-29]. Inadequate water temperature, poorly designed or installed drinking-water systems, inadequate disinfection after overhaul, scaling and corrosion in the system all positively impact the growth of Legionella spp. bacteria in a ship's drinking-water system [7, 29]. WHO states that almost 200 cases of Legionnaires disease between 1970 and 2000 were associated with ships. Most incidents involved one or two individuals on passenger ships. There is very little information available on the prevalence of Legionnaires disease on merchant ships. Serological tests of seafarers suggest that one third of them have Legionella pneumophila antibodies. Drinking-water and air-conditioning systems on general cargo ships of are contaminated with Legionella pneumophila bacteria. Potential sources of legionellas on ships are humidifiers, parts of the piping where water stagnates or collects, air-conditioning systems, rooms on ships with higher room temperatures and the ship's water storage and distribution system [2, 27-29].

All employees working on the drinking-water system must be properly trained. The port authority is responsible for ensuring that safe, wholesome and clean, drinking water is loaded into the ship. If in doubt regarding the origin of water and concerns that it might come from an unsafe water source, the ship captain shall decide on additional water treatment to be applied (hyperchlorination or filtration). Great caution is required when dealing with sources from countries with inadequate hygienic-epidemiological standards. In the event of water treatment, the treatment to be applied must be the one that is most pertinent to the needs and that is most manageable for the ship's crew and officers [2, 6, 9, 12].

\section{CONCLUSIONS}

The system and organisation of water supply to and on the ship differs largely from the water supply system on the land; however, the same safety standards apply for drinking water on land and on board ships. The complicated water supply system on ships contains many risk points involving possible exposure to contamination. Pursuant to all international regulations, passengers and crew members have the right to sufficient quantities of drinking-water, and it is the ship operator's duty to provide it. Crews of merchant and passenger marines and tourists travelling on cruise ships are all exposed to the risk of waterborne infections. There are many points of risk and ways of drinking-water contamination on ships, but contamination can also arise from the port water source or during water loading, storage or distribution on ships. Outbreaks of waterborne diseases on ships can be prevented or at least their incidence reduced. Factors contributing to the occurrence and spread of outbreaks highlight that ships need to be managed in line with the hygienic and health-care standards along the entire water supply chain, from the source to the point of consumption. Engine and deck officers must all be trained on supervision procedures and on how to maintain high hygienic standards, as well as on the risk points during drinking-water supply on board ships.

\section{REFERENCES}

1. Council Directive 98/83/EC of 3 November 1998 on the quality of water intended for human consumption, Official Journal of the European Communities, L 330/32, 15/vol. 6. Internet. 1998. https://eur-lex.europa.eu/legal-content/EN/TXT/PDF/?uri=CELEX:31998L0083\&from=EN (accessed on 4th Feb 2020).

2. WHO: Water for Health, Taking Charge, World Health Organization, Geneva, 2001 Internet. 2001. https://apps.who.int/iris/bitstream/ handle/10665/66717/WHO_WSH_WWD_01.1.pdf;jsessionid=A5F7083BC49A7A2COF39868EECFF44B9?sequence=1 (accessed on 4th Feb 2020).

3. Puntarić D. Voda i zdravlje. Zdravstvena ekologija. Zagreb: Medicinska naklada. 2012.

4. Rooney RM, Bartram JK, Cramer EH, et al. A review of outbreaks of waterborne disease associated with ships: evidence for risk management. Public Health Rep. 2004; 119(4): 435-442, doi: 10.1016/j. phr.2004.05.008, indexed in Pubmed: 15219801.

5. Bert F, Scaioli G, Gualano MR, et al. Norovirus outbreaks on commercial cruise ships: a systematic review and new targets for the public health agenda. Food Environ Virol. 2014; 6(2): 67-74, doi: 10.1007/s12560-014-9145-5, indexed in Pubmed: 24838574.

6. Oldenburg M, Huesing UP, Kalkowski M, et al. Chemical contamination of potable water in ship tanks. Int Marit Health. 2007; 58(1-4): 79-91, indexed in Pubmed: 18350978.

7. Guide to Ship Sanitation, 3rd edition, World Health Organization, Geneva, 2011. Internet. 2011. https://www.ncbi.nlm.nih.gov/books/ NBK310823/\#ch2.s8 (accessed on 4th Feb 2020).

8. Grappasonni I, Cocchioni M, et al. Degli Angioli E Recommendations for assessing water quality and safety on board merchant ships. Int Marit Health. 2013; 64(3): 154-159. 
9. WHO. Guidelines for Drinking-Water Quality, 14thedition, WHO, Geneva, 2017. Internet. 2017. https://apps.who.int/iris/bitstream/ handle/10665/254637/9789241549950-eng.pdf ?sequence $=1$ (accessed on 4th Feb 2020).

10. 10. Reporting on Drinking Water Directive. Special Report, 12, 2017. Internet. 2017 pristupljeno 4. veljače 2020. https://op.europa. eu/webpub/eca/special-reports/drinking-water-12-2017/hr/\#B4 (accessed on 27th Nov 2019).

11. Kralj P, Šeljuga I. Priručnik iz brodskih cjevovoda za studijske programe BS, EITP, NTPP te programe cjeloživotnog učenja. Internet. 2019. https://www.pfri.uniri.hr/web/dokumenti/uploads_nastava/20180216_115257_kralj_PRIRU.NIK.BRODSKI_CJEVOVODI_ZA_WEB.pdf (accessed on 11th Jan 2020).

12. Mulić R, Ropac D. Medicina za pomorce. Zagreb, Medicinska naklada. 2003: 154-159.

13. Lee S. Managing water quality on board passenger vessels to ensure passenger and crew safety. Perspect Public Health. 2019; 139(2): 70-74, doi: 10.1177/1757913919828960, indexed in Pubmed: 30880607.

14. 13. Ordinance on the conformity parameters, methods of analysis, monitoring and plans concerning the safety of water for human consumption and the manner of keeping the registry of legal entities performing public water supply services. (In Croatian). Official Gazette. 125, 2017. http://www.propisi.hr/print.php?id=12622 (accessed: January 15, 2020).

15. 14. Act on Water intended for Human Consumption. (In Croatian). Official Gazette. 56/13, 64/15, 104/17, 115/18. [Internet]. 2019. https://www.zakon.hr/z/584/Zakon-o-vodi-za-ljudsku-potro\%C5\%A1nju (accessed on 11th Jan 2020).

16. 15. Maritime Labour Convention. (In Croatian). Pomorski glasnik. Ministry of the Sea, Tourism, Transport and Development, Zagreb, 2006. [Internet]. 2006. https://sph.hr/upload/2012/10/konvencija_o_radu_pomoracahr_i_eng_2_507e761e3e18e.pdf (accessed on 11th Jan 2020).

17. Petrović D. Global Rights for Seafarers: A New Maritime Labour Convention. Naše more 2006;53(1-2. : 29-33.

18. IMO. Life Saving Appliances. IMO, 2010. https://www.academia. edu/8592685/LIFE_SAVING_APPLIANCES_LSA_CODE?auto=download (accessed on 11th Jan 2020).
19. 17. WHO. International Health Regulations (third edition). WHO, Geneva, 2005. Internet. 2010. https://www.who.int/ihr/publications/9789241580496/en/ (accessed on 11th Jan 2020).

20. Daniels NA, Neimann J, Karpati A, et al. Traveler's diarrhea at sea: three outbreaks of waterborne enterotoxigenic Escherichia coli on cruise ships. J Infect Dis. 2000; 181(4): 1491-1495, doi: 10.1086/315397, indexed in Pubmed: 10762583.

21. Giddings S, Stevens A, Leung D. Traveler's diarrhea. Medical Clinics North Am. 2016; 100(2): 317-330, doi: 10.1016/j. mcna.2015.08.017.

22. Grappasonni I. Clean and healthy - Built environments and health: Quality of 2018, pp 183-life in an urban context. Urban Book Series. 2018; 15: 183-193, doi: 10.1007/978-3-319-65581-9.

23. WHO. Domestic Water Quality Service. Level and Health. Internet. 2003. https://www.who.int/water_sanitation_health/diseases/ WSH03.02.pdf (accessed on 5th May 2020).

24. Serdarevic F, Jones RC, Weaver KN, et al. Multi-pathogen waterborne disease outbreak associated with a dinner cruise on Lake Michigan. Epidemiol Infect. 2012; 140(4): 621-625, doi: 10.1017/ S0950268811000896, indexed in Pubmed: 21676362.

25. Minooee A, Rickman LS. Infectious diseases on cruise ships. Clin Infect Dis. 1999; 29(4): 737-43; quiz 744, doi: 10.1086/520426, indexed in Pubmed: 10589880.

26. 24. Government of the Republic of Croatia. Regulation on the terms that ports must abide by. Internet. 1995 . https://mmpi.gov.hr/UserDocsImages/arhiva/95_0437.htm (accessed on 17th Jan 2020).

27. Pavić D, Kralj P, Lenac D. Legionella pneumophila on board ship's fresh water systems and technological and organizational measures of prevention and suppression. Scien J Marit Res. 2017; 31: $74-76$.

28. 26. WHO. Legionella and the prevention of legionellosis Ship-associated cases. WHO, Geneva 2007:106. [Internet]. 2007. https:// www.who.int/water_sanitation_health/emerging/legionella.pdf (accessed on 17th Jan 2020).

29. Mouchtouri VA, Bartlett CLR, Diskin A, et al. Water Safety Plan on cruise ships: a promising tool to prevent waterborne diseases. Sci Total Environ. 2012; 429: 199-205, doi: 10.1016/j.scitotenv.2012.04.018, indexed in Pubmed: 22608187. 